\title{
Effect of wind damage on the habitat suitability of saproxylic species in a boreal forest landscape
}

\author{
Ane Zubizarreta-Gerendiain ${ }^{1} \cdot$ Timo Pukkala $^{1} \cdot$ Heli Peltola ${ }^{1}$
}

Received: 5 January 2018/Accepted: 29 January 2018/Published online: 14 May 2018

(C) The Author(s) 2018

\begin{abstract}
Many forest-dwelling species are dependent on deadwood. Sources of deadwood include competition- and senescence-related mortality of trees, and various damages. This study described a methodology for predicting the effect of wind damage on the amount of deadwood and suitability of the forest for saproxylic species. The methodology was used in a forested boreal landscape of 360 ha to analyze the effects of wind damage on the habitat quality for 27 groups of saproxylic species differing in their requirements for the species, size and decay stage of deadwood objects. A reference plan maximized net present value (MaxNPV) while others either minimized or maximized height differences between adjacent stands. Maximization of height differences resulted in high amount of wind damage and deadwood while minimizing height differences minimized wind damage and the amount of damage-related deadwood. The fourth plan maximized the average habitat suitability index (HSI) of the 27 groups of saproxylic species. The plans were compiled with and without even-flow harvesting constraints for three 10-year
\end{abstract}

Project funding: This work was partly funded by the UEF foundation (Project 930341), the University of Eastern Finland. It was also supported by the FORBIO project (Decision Number 293380) funded by the Strategic Research Council of the Academy of Finland, led by Prof. Heli Peltola at University of Eastern Finland.

The online version is available at http://www.springerlink.com

Corresponding editor: Yu Lei.

Timo Pukkala

timo.pukkala@uef.fi

1 School of Forest Sciences, Faculty of Science and Forestry, University of Eastern Finland, PO Box 111, 80101 Joensuu, Finland periods. Maximization of height differences between adjacent stands resulted in higher HSI values than obtained in the MaxNPV plan or in the plan than minimized height differences between adjacent stands. The average HSI of shade-demanding species correlated negatively with the amount of harvested timber. No strong correlations were found for light-demanding and indifferent species.

Keywords Biodiversity · Habitat suitability index · Deadwood · Wind disturbance $\cdot$ Optimization $\cdot$ Simulated annealing

\section{Introduction}

In managed boreal forests, the amount of deadwood is usually too low for a high diversity of saproxylic species. For example, in southern Finland the average quantity of deadwood (without the stumps of harvested trees) is only $3 \mathrm{~m}^{3} \mathrm{ha}^{-1}$, which is $21 \%$ of the amount found in natural forests (Finnish Statistical Yearbook of Forestry 2014). In boreal conditions, $20-25 \%$ of species living in the forest are dependent on deadwood (they are called saproxylic species). Majority of saproxylic species require over $20 \mathrm{~m}^{3} \mathrm{ha}^{-1}$ deadwood of certain host tree species in a certain stage of wood decay (Müller and Bütler 2010; Lassauce et al. 2011; Gossner et al. 2013). The species may also have different preferences for microclimatic conditions (Tikkanen et al. 2006, 2007; Kouki and Tikkanen 2007). Some species need moist and shady microclimate while others prefer warm and sunny sites, or have no specific microclimatic requirements.

Many saproxylic species are red-listed, having few suitable habitats in managed forests (Mönkkönen 1999; Siitonen 2001; Junninen et al. 2006; Tikkanen et al. 2006; 
Lassauce et al. 2012). However, forest disturbances such as wind damage and related bark beetle attacks may increase the amount of coarse woody debris (CWD) in managed forests (Stadelmann et al. 2013; Beudert et al. 2015; Thom and Seidl 2016; Kulakowski et al. 2017; Thorn et al. 2014, 2017). In Finland, winter and summer storms damaged a total of 24 million $\mathrm{m}^{3}$ of timber between 2001 and 2014, with the highest timber losses in 2001 (7.3 million $\mathrm{m}^{3}$ ) and 2010 (8.1 million $\mathrm{m}^{3}$ ) (Gregow 2013). Finland also experienced strong winds in 2002, 2011, 2012, 2013, and 2014 , with the annual damage ranging from 0.3 to 4 million $\mathrm{m}^{3}$.

Most wind damage occurs in mature stands adjacent to newly clear-cut areas or in heavily thinned stands (Laiho 1987; Zubizarreta-Gerendiain et al. 2012). Therefore, the risk of wind damage may be decreased by avoiding new vulnerable edges and cutting the most vulnerable stands, especially when they do not provide shelter to other stands (Tarp and Helles 1997; Meilby et al. 2001; Zeng et al. 2007). The rotation length of unsheltered stands should be shortened in the presence of a high risk of wind damage, while stands providing wind shelter to other stands should have longer rotations (Meilby et al. 2001). A smooth landscape structure with small height differences between adjacent stands is known to decrease the risk of wind damage (Heinonen et al. 2009; Seidl et al. 2014; Zubizarreta-Gerendiain et al. 2017). The amount of wind damage can be predicted for a certain stand based on the characteristics of the stand itself and its immediate neighbors (Meilby et al. 2001; Zeng et al. 2007; Heinonen et al. 2009), making it possible to evaluate the potential effects of wind damage on the amount of deadwood and, consequently, the habitat suitability for saproxylic species.

The present study developed a methodology for predicting the amount and location of wind damage under a certain management plan and calculating the effect of damaged trees on the habitat quality of saproxylic forest species. Earlier research (Tikkanen et al. 2007; Tikkanen et al. 2007) has developed models for calculating habitat suitability indices (HSI) for 27 groups of forest-dwelling saproxylic species based on stand density and the amount and type of deadwood. The groups have different requirements for stand density (microclimatic conditions) as well as the species, size and stage of decomposition of deadwood objects. The developed methodology was tested in a boreal forest potentially suitable for these 27 groups of saproxylic species. A reference plan maximized the net present value (MaxNPV), while others either minimized (MinRisk) or maximized (MaxRisk) the risk of wind damage, via minimizing or maximizing height differences between adjacent stands. The fourth plan (MaxBio) maximized the mean HSI of the 27 groups of saproxylic species. The four management plans were compiled with and without even-flow harvesting constraints for three 10 -year periods.

\section{Materials and methods}

\section{Overview}

We used the Monsu forest planning software (Pukkala 2004, 2008) for simulating stand development and optimizing management. The software also calculated the amounts of wind damage and deadwood, and the HSI values for different groups of saproxylic species. In a recent study by Zubizarreta-Gerendiain et al. (2017), the Monsu software was augmented with a component that simulates wind damage at stand borders. The HSI models used in this study for different groups of saproxylic forest species were introduced into Monsu by Pukkala (2008), based on Tikkanen et al. (2007) and Kouki and Tikkanen (2007).

The analyses of this study consisted of the following steps (Fig. 1):

1. Alternative treatment schedules were simulated for all stands in the forest landscape without predicting the amount of wind damage.

2. The optimal combination of management schedules was found by numerical optimization. Four plans (all with and without even-flow harvesting constraint) were compiled, being here on referred to as MaxNPV, MinRisk, MaxRisk, and MaxBio (Table 1). The optimal solutions provided information on tree height development of every stand in the studied forest landscape.

3. The optimal schedules selected for the stands in Step 2 were simulated again, this time including the

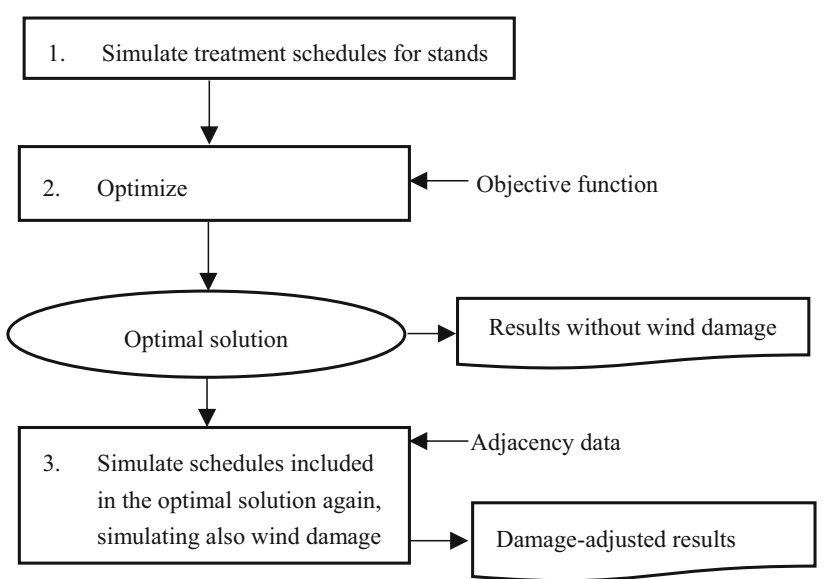

Fig. 1 Flow chart of the method used to analyse the effects of wind damage on the habitat suitability of saproxylic forest species 
Table 1 Optimization problems

\begin{tabular}{ll}
\hline $\begin{array}{l}\text { Short } \\
\text { name }\end{array}$ & Description \\
\hline $\begin{array}{l}\text { MaxNPV } \\
\text { MinRisk }\end{array}$ & $\begin{array}{c}\text { NPV was maximized as the only objective } \\
\text { objectives }\end{array}$ \\
MaxRisk & $\begin{array}{c}\text { Wind damage risk was maximized by maximizing average height difference between adjacent stands. NPV and biodiversity were } \\
\text { not objectives }\end{array}$ \\
MaxBio & $\begin{array}{c}\text { Biodiversity was maximized as the only objective by maximizing the mean habitat suitability index of } 27 \text { groups of saproxylic } \\
\text { species }\end{array}$ \\
\hline
\end{tabular}

simulation of wind damage at stand edges, considering the shelter provided by adjacent stands. Decomposition of all dead trees (competition-induced mortality and wind-thrown trees) was simulated, making it possible to calculate the amount of deadwood in different stages of decomposition.

The method was applied to a case study forest representing the same region for which the HSI models were developed (eastern Finland). The site and growing stock characteristics are true forest inventory data from eastern Finland. The stand borders are from a forest holding where the forest cover is continuous (Fig. 2), which was regarded a useful property for the purposes of the current study. The case study forest consists of 360 ha and 245 stand compartments and is dominated by Scots pine (Pinus sylvestris) and Norway spruce (Picea abies), followed by birch (Betula pendula and B. pubescens) and other broadleaves (Table 2). The growing sites are fertile as 201.3 ha represent herb-rich sites (Oxalis-Myrtillus type), 131.3 ha mesic sites (Myrtillus type), 17.7 ha sib-xeric sites (Vaccinium type), 7.7 ha xeric sites (Calluna type) and 1.7 ha was nonproductive stunted forest.

\section{Simulation of treatment schedules}

Several alternative treatment schedules were simulated for each stand for three consecutive 10-year periods. A set of variables was calculated for each schedule, including growing stock volume, volume of harvested timber, NPV, deadwood volume by species, diameter class and stage of decomposition, and the HSI values. The currently recommended thinning thresholds (stand basal area at which thinning is recommended) and mean stem diameter at breast height required for final felling were applied (Äijälä et al. 2014). Additional schedules were simulated postponing either the thinning treatments or the final felling, as well as simulating stand development without any cuttings (Pukkala 2004).

All simulations represented even-aged management. Clear felling followed by planting or sowing was used as the main regeneration method, except for Scots pine grown at sub-xeric and poorer sites, where seeding or natural regeneration with seed trees was used (Äijälä et al. 2014). Seedlings of various tree species were also expected to born naturally on all sites. Tending treatment of dense seedling and sapling stands were simulated according to
Fig. 2 Mean tree height of different stands at the end of the 30 -year planning horizon when the height difference between adjacent stands is maximized (a) or minimized (b). Dark tone indicates large tree height. Harvested timber volume is the same in both cases $\left(25,000 \mathrm{~m}^{3}\right.$ during each 10 -year period)
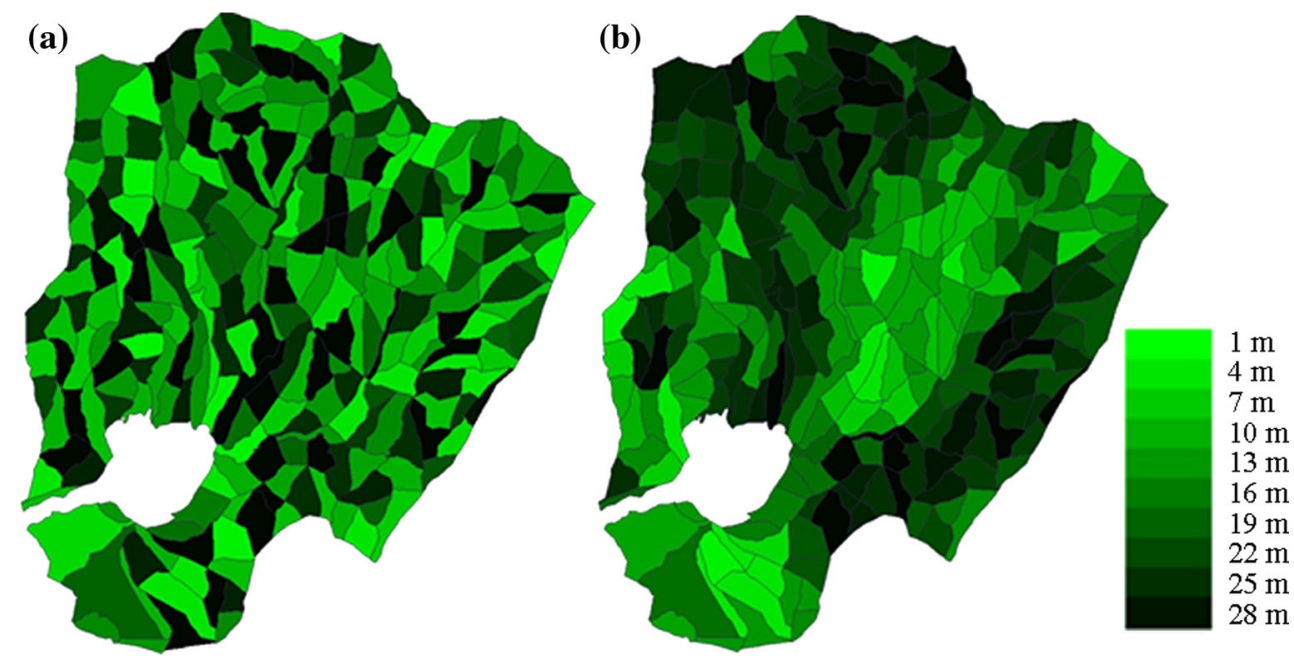
Table 2 Volume of growing stock by tree species at the beginning of the simulations (year 2017) in the studied forest area

\begin{tabular}{lllc}
\hline Species & Saw $\operatorname{logs}\left(\mathrm{m}^{3} \mathrm{ha}^{-1}\right)$ & Pulpwood $\left(\mathrm{m}^{3} \mathrm{ha}^{-1}\right)$ & Total volume $\left(\mathrm{m}^{3} \mathrm{ha}^{-1}\right)$ \\
\hline Pinus sylvestris & 49.3 & 33.8 & 83.1 \\
Picea abies & 33.6 & 15.7 & 49.3 \\
Betula pendula & 7.9 & 17.6 & 25.5 \\
Betula pubescens & 0.3 & 5.1 & 5.4 \\
Populus tremula & 0.7 & 4 & 4.7 \\
Alnus incana & 0 & 3.8 & 3.8 \\
Sorbus aucuparia & 0 & 0.1 & 0.1 \\
Salix caprea & 0 & 0.3 & 0.3 \\
Total & 82.7 & 80.3 & 172.1 \\
\hline
\end{tabular}

the recommendations. Uniform thinning was used whenever thinning was applied, removing the same percentage of trees from all diameter classes.

The individual-tree models of Pukkala et al. (2013) were used to simulate tree growth, competition-induced mortality, and tree recruitment. The decomposition of each dead tree was also simulated and the species-specific total dry masses of deadwood were calculated using three tree size classes (diameter class $<10 \mathrm{~cm}, 10-30 \mathrm{~cm}$ and $>30$ $\mathrm{cm}$ ) and five different wood decay stages classes (I-V, grade $\mathrm{V}$ being the most decomposed). Decomposition of the stems of dead trees was simulated by using the decay curve $Y_{t}=Y_{0} \times \exp (-k t)$ where $t$ is time since death and $k$ is annual decay rate $\left(Y_{0}\right.$ is dry mass at the moment of death and $Y_{t}$ is remaining dry mass after $t$ years of decomposition). The annual decomposition rate $(k)$ was calculated separately for each dead tree using the models of Pukkala (Fig. 3 in Pukkala 2006). The models for decay rate are based on measured wood density of logs representing different decay stages and the results of Tarasov and Birdsey (2001) for boreal tree species (Tikkanen et al. 2007; Kouki and Tikkanen 2007).

Stem taper models (Laasasenaho 1982) were used to calculate the volumes of different timber assortments, with the minimum top diameters and roadside prices used for different tree species and timber assortments shown in
Table 3. Harvesting costs calculated via harvesting cost functions (Rummukainen et al. 1995) were subtracted from the roadside value of harvested trees to obtain the net income from cutting. To calculate the NPV of a treatment schedule, all costs and incomes for the simulated 30-year period were discounted to the beginning of the period using a $4 \%$ discount rate. The NPV of the final growing stock was calculated with models (Pukkala 2005) and included in the NPV of each schedule.

\section{Calculation of habitat suitability indices}

We employed the HSI models of Tikkanen et al. (2007) and Kouki and Tikkanen (2007) for 27 groups of saproxylic forest species. These expert models are based on reported relationships between the amount of deadwood and the richness of saproxylic species (Martikainen et al. 2000; Similä et al. 2003; Penttilä et al. 2004; Junninen et al. 2006). The groups were named by one species that typifies the group. A group consisted of saproxylic species that are dependent on deadwood of the same species, size and stage of decomposition. The groups also differ in their requirements for microclimatic conditions (shade-demanding, light-demanding or indifferent). Microclimatic conditions were described by the total basal area of the stand and the proportion of Norway spruce of growing stock volume as
Table 3 Minimum top diameters and roadside prices used for different tree species and timber assortments

\begin{tabular}{|c|c|c|c|c|}
\hline \multirow[t]{2}{*}{ Tree species } & \multicolumn{2}{|c|}{ Roadside prices $\left(€ \mathrm{~m}^{-3}\right)$} & \multicolumn{2}{|c|}{$\begin{array}{l}\text { Minimum top diameter } \\
(\mathrm{cm})\end{array}$} \\
\hline & Saw logs & Pulpwood & Saw logs & Pulpwood \\
\hline Pinus sylvestris & 58 & 30 & 15 & 7 \\
\hline Picea abies & 58 & 31 & 16 & 8 \\
\hline Betula pendula & 48 & 30 & 18 & 7 \\
\hline Betula pubescens & 44 & 30 & 18 & 7 \\
\hline Populus tremula & 40 & 20 & 17 & 7 \\
\hline Alnus incana & - & 10 & - & 7 \\
\hline Sorbus aucuparia & - & 10 & - & 7 \\
\hline Salix caprea & - & 10 & - & 7 \\
\hline
\end{tabular}


Norway spruce casts more shade than the other species and increases the moisture of forest floor.

The HSI values were calculated as follows:

$H S I_{t}= \begin{cases}\left(\text { Envoronment }_{t} \times \text { Resource }_{t}\right)^{1 / 2} & \text { for } t=1 \\ \left(\text { Envoronment }_{t} \times \text { Resource }_{t} \times H S I_{t-1}\right)^{1 / 3} & \text { for } t>1\end{cases}$

where Environment describes shading conditions, Resource describes the availability of suitable deadwood and $t$ refers to 10-year period (Pukkala 2008). Both sub-indices (Environment and Resource) range from 0 to 1 . In the HSI models, Environment equals to 1 for species indifferent to shading conditions. The HSI value of the previous period $(t-1)$ affected the HSI (except for the first period, for which the earlier HSI was unknown) to account for the requirement for temporal continuity. If the HSI of the previous period was $<0.1,0.1$ was used in calculations, which means that a stand, which was initially unsuitable for certain species group, could gradually become a suitable habitat. All stands with HSI greater than 0.5 were considered suitable habitats for the species group.

\section{Optimization}

Management was optimized using the treatment schedules that were simulated without wind damage. The following four optimization problems were solved (Table 1): (1) maximizing NPV (MaxNPV); (2) minimizing the risk of wind damage by minimizing the mean height difference between adjacent stands (MinRisk); (3) maximizing the risk of wind damage by maximizing the mean height difference between adjacent stands (MaxRisk); and (4) maximizing the mean HSI value of the 27 groups of saproxylic species (maximizing biodiversity, MaxBio). In the optimization for the fourth plan (MaxBio), the HSIs were calculated without the effect of wind-damaged trees since damage was not predicted at this stage of the analysis (Fig. 1).

The optimization problems were formulated as follows:

$\max$ or $\min z=Z(\mathbf{x})$

subject to:

$q_{i}=Q_{i}(\mathbf{x})=25,000, \quad i=1, \ldots, 3$

where $z$ is the objective function (NPV, mean height difference between adjacent stands or the mean HSI of the 27 groups of saproxylic species), $Z$ is the procedure employed to calculate the value of the objective function from the information for treatment schedules included in the solution, $q_{i}$ is the volume harvested during 10-year period $i, Q_{i}$ is the procedure employed to calculate the harvested volume of the solution, and $\mathbf{x}$ is a vector indicating the ID numbers of those schedules included in the solution. Since two of the problems (MinRisk and MaxRisk) were spatial, a heuristic method (simulated annealing) was used to find the optimal combination of the simulated treatment schedules (Lockwood and Moore 1992).

Plans were also compiled without even-flow harvesting constraints for the three 10-year time periods, resulting in a total of eight management plans. In the management plans that included the even-flow constraint, the cutting target was nearly equal to the volume increment of the forest, thereby maintaining a more or less stable forest biomass throughout the analyzed 30-year period.

\section{Calculation of wind damage}

Wind damage was calculated following the approach used in a previous study (Zubizarreta-Gerendiain et al. 2017). In this approach, schedules that belonged to the optimal management plans were simulated again so that wind damage was also simulated (Fig. 1). This yielded damageadjusted results for the amount of deadwood, HSI, NPV and the total amount of harvested timber. The critical wind speeds (CWS) needed to uproot trees at stand edges were calculated based on the characteristics of both the subject stand (tree species, mean tree height and breast height diameter to height ratio) and the adjacent stand (mean height and area of the stand), using the approach developed by Heinonen et al. (2009). Based on wind speed statistics and the CWS predicted for a stand edge, the probability that wind speed exceeds the threshold speed during a 5-year period was calculated (Zubizarreta-Gerendiain et al. 2017). We assumed that CWS increases sharply within one tree height from the stand edge (Peltola et al. 1999) with a consequence that wind damage occurs only near stand edge. It was assumed that $3 \%$ of trees within the edge zone are uprooted or broken in a wind damage event, based on wind damage measurements in Finland in 2001 after the Pyry, Mielikki and Janika storms (Zubizarreta-Gerendiain et al. 2012).

\section{Results}

\section{Habitat suitability for saproxylic species}

At the beginning of the simulation (year 2017), the mean HSI value for all species groups was 0.102 (Table 4). The highest mean HSI value (0.179) over all species groups was obtained at the end of the 30-year simulation period for a fragmented forest landscape (MaxRisk plan with even-flow harvesting constraint). The lowest mean HSI value (0.151) was obtained for a smooth forest landscape (MinRisk plan without even-flow constraint) (Table 4). Thus, minimizing 
Table 4 Average habitat suitability index, microclimate (indifferent, shade, and sunny) and host species for each forest species group at the beginning (2017) and final year of simulation (2047) when maximizing NPV (MaxNPV), minimizing wind risk (MinRisk), maximizing wind risk (MaxRisk) and maximizing biodiversity (MaxBio), with and without an even-flow cutting target

\begin{tabular}{|c|c|c|c|c|c|c|c|c|c|c|c|c|}
\hline \multirow[t]{2}{*}{ Species group } & \multirow[t]{2}{*}{ Type } & \multirow{2}{*}{$\begin{array}{l}\text { Micro- } \\
\text { climate }\end{array}$} & \multirow{2}{*}{$\begin{array}{l}\text { Host } \\
\text { species }\end{array}$} & \multirow[t]{2}{*}{2017} & \multicolumn{4}{|c|}{ Even-flow harvesting } & \multicolumn{4}{|c|}{ No even-flow harvesting } \\
\hline & & & & & $\begin{array}{l}\text { Max } \\
\text { NPV } \\
2047\end{array}$ & $\begin{array}{l}\text { Min } \\
\text { risk } \\
2047\end{array}$ & $\begin{array}{l}\text { Max } \\
\text { risk } \\
2047\end{array}$ & $\begin{array}{l}\text { Max } \\
\text { bio } \\
2047\end{array}$ & $\begin{array}{l}\text { Max } \\
\text { NPV } \\
2047\end{array}$ & $\begin{array}{l}\text { Min } \\
\text { risk } \\
2047\end{array}$ & $\begin{array}{l}\text { Max } \\
\text { risk } \\
2047\end{array}$ & $\begin{array}{l}\text { Max } \\
\text { bio } \\
2047\end{array}$ \\
\hline Total average & & & & 0.102 & 0.174 & 0.164 & 0.179 & 0.175 & 0.160 & 0.151 & 0.167 & 0.174 \\
\hline \multirow[t]{3}{*}{ Average } & & Indiff. & & 0.128 & 0.210 & 0.199 & 0.214 & 0.212 & 0.199 & 0.181 & 0.199 & 0.206 \\
\hline & & Shade & & 0.045 & 0.105 & 0.099 & 0.112 & 0.108 & 0.092 & 0.102 & 0.105 & 0.119 \\
\hline & & Sunny & & 0.160 & 0.234 & 0.221 & 0.239 & 0.233 & 0.217 & 0.190 & 0.221 & 0.219 \\
\hline Pytho abieticola & VU & Indiff. & Picea & 0.16 & 0.25 & 0.22 & 0.26 & 0.25 & 0.24 & 0.19 & 0.24 & 0.22 \\
\hline $\begin{array}{l}\text { Erastia } \\
\quad \text { salmonicolor }\end{array}$ & VU & Indiff. & Conifers & 0.15 & 0.34 & 0.33 & 0.35 & 0.34 & 0.35 & 0.31 & 0.34 & 0.32 \\
\hline Antrodia primaeva & VU & Indiff. & Pinus & 0 & 0.08 & 0.08 & 0.09 & 0.08 & 0.09 & 0.06 & 0.09 & 0.07 \\
\hline $\begin{array}{l}\text { Ceruchus } \\
\text { chrysomelinus }\end{array}$ & EN & Indiff. & Conifers & 0 & 0.01 & 0.01 & 0.01 & 0.01 & 0.02 & 0.01 & 0.01 & 0.01 \\
\hline $\begin{array}{l}\text { Bothrideres } \\
\text { contractus }\end{array}$ & $\mathrm{CR}$ & Indiff. & Pinus & 0.14 & 0.24 & 0.23 & 0.25 & 0.24 & 0.21 & 0.19 & 0.23 & 0.23 \\
\hline Zavaljus brunneus & VU & Indiff. & Decid. & 0.31 & 0.28 & 0.26 & 0.28 & 0.28 & 0.22 & 0.27 & 0.24 & 0.32 \\
\hline Ditylus laevis & EN & Indiff. & Conifers & 0.27 & 0.49 & 0.47 & 0.51 & 0.49 & 0.47 & 0.40 & 0.47 & 0.46 \\
\hline Wagaicis wagai & $\mathrm{CR}$ & Indiff. & Populus & 0.12 & 0.16 & 0.15 & 0.14 & 0.17 & 0.15 & 0.16 & 0.13 & 0.17 \\
\hline Hololepta plana & VU & Indiff. & Populus & 0 & 0.04 & 0.04 & 0.04 & 0.05 & 0.04 & 0.04 & 0.04 & 0.05 \\
\hline $\begin{array}{l}\text { Amyloporia } \\
\text { sitchensis }\end{array}$ & EN & Shade & Picea & 0 & 0.03 & 0.03 & 0.03 & 0.03 & 0.03 & 0.03 & 0.04 & 0.03 \\
\hline Amyloporia crassa & EN & Shade & Pinus & 0 & 0.06 & 0.06 & 0.07 & 0.06 & 0.05 & 0.06 & 0.08 & 0.07 \\
\hline Oligoporus lowei & VU & Shade & Pinus & 0.12 & 0.23 & 0.23 & 0.24 & 0.23 & 0.20 & 0.24 & 0.22 & 0.27 \\
\hline $\begin{array}{l}\text { Piloporia } \\
\text { sajanensis }\end{array}$ & EN & Shade & Picea & 0.04 & 0.11 & 0.11 & 0.11 & 0.12 & 0.12 & 0.10 & 0.12 & 0.11 \\
\hline $\begin{array}{c}\text { Antrodiella } \\
\text { citrinella }\end{array}$ & NT & Shade & Picea & 0.15 & 0.24 & 0.23 & 0.24 & 0.24 & 0.21 & 0.25 & 0.22 & 0.27 \\
\hline Pytho kolwensis & EN & Shade & Picea & 0.04 & 0.13 & 0.12 & 0.14 & 0.14 & 0.13 & 0.11 & 0.14 & 0.13 \\
\hline Cybebe gracilenta & VU & Shade & Betula & 0.11 & 0.08 & 0.07 & 0.09 & 0.08 & 0.06 & 0.08 & 0.08 & 0.11 \\
\hline Cyphaea latiuscula & VU & Shade & Picea & 0.03 & 0.09 & 0.08 & 0.10 & 0.10 & 0.09 & 0.07 & 0.09 & 0.09 \\
\hline Gloiodon strigosus & NT & Shade & Populus & 0 & 0 & 0 & 0 & 0 & 0 & 0 & 0 & 0 \\
\hline $\begin{array}{l}\text { Protomerulius } \\
\text { caryae }\end{array}$ & NT & Shade & Betula & 0 & 0.09 & 0.08 & 0.10 & 0.09 & 0.06 & 0.09 & 0.08 & 0.11 \\
\hline $\begin{array}{l}\text { Rigidoporus } \\
\text { crocatus }\end{array}$ & EN & Shade & Decid. & 0 & 0.10 & 0.08 & 0.11 & 0.10 & 0.06 & 0.09 & 0.09 & 0.12 \\
\hline $\begin{array}{l}\text { Xyletinus } \\
\text { tremulicola }\end{array}$ & VU & Sunny & Populus & 0 & 0.04 & 0.04 & 0.03 & 0.04 & 0.03 & 0.03 & 0.03 & 0.04 \\
\hline Tropideres dorsalis & VU & Sunny & Decid. & 0.28 & 0.22 & 0.21 & 0.22 & 0.22 & 0.19 & 0.20 & 0.20 & 0.24 \\
\hline $\begin{array}{l}\text { Drapetes } \\
\quad \text { mordelloides }\end{array}$ & EN & Sunny & Decid. & 0.31 & 0.27 & 0.25 & 0.27 & 0.28 & 0.22 & 0.25 & 0.24 & 0.29 \\
\hline Boros schneideri & VU & Sunny & Pinus & 0.07 & 0.17 & 0.16 & 0.18 & 0.17 & 0.15 & 0.13 & 0.17 & 0.16 \\
\hline $\begin{array}{l}\text { Acmaeops } \\
\text { septentrionis }\end{array}$ & NT & Sunny & Pinus & 0.10 & 0.22 & 0.21 & 0.23 & 0.22 & 0.21 & 0.17 & 0.22 & 0.19 \\
\hline $\begin{array}{l}\text { Dichomitus } \\
\text { squalens }\end{array}$ & VU & Sunny & Pinus & 0.15 & 0.32 & 0.30 & 0.33 & 0.31 & 0.32 & 0.24 & 0.31 & 0.27 \\
\hline Lacon fasciatus & LC & Sunny & Conifers & 0.21 & 0.40 & 0.38 & 0.41 & 0.39 & 0.40 & 0.31 & 0.38 & 0.34 \\
\hline
\end{tabular}

Source: https://laji.fi (Finnish biodiversity info facility)

$L C$ least concern, $N T$ near threatened, $V U$ vulnerable, $E N$ endangered, $C R$ critically endangered 
the risk of wind damage by reducing height differences between adjacent stands reduced the mean HSI value. Even-flow harvesting constraint reduced the influence of the objective variable on the HSI values (Table 4).

At the beginning of the simulation, the light-demanding species groups had the highest average HSI value (0.160), and the shade-preferring species group the lowest (0.045). The highest average HSI values at the end of the 30-year simulation period were predicted for the light-demanding species group (0.190-0.239), followed by species groups indifferent to microclimatic conditions (0.181-0.214). Species groups preferring shade had the lowest HSI values at the end of the 30-year period (0.092-0.119).

When wind damage was not simulated, the mean HSI values were underestimated by $22-50 \%$ depending on the management plan, the most for the MaxRisk plan and the least for the MaxBio plan (Fig. 3). The mean HSIs of the three microclimatic groups were underestimated by 32-50\% (light-demanding species), 24-49\% (indifferent species), and 22-44\% (shade-demanding species), depending on management plan.

The suitable habitat areas for the different species groups varied in the same way as the HSI values. At the end of the 30-year simulation period, the suitable habitat area (HSI $>0.5$ ) was 35-53 ha for indifferent species groups, 32-52 ha for light-demanding species groups, and 4-16 ha for shade-demanding species groups, depending on management plan (Fig. 4). The smallest habitat areas were usually obtained for the MinRisk plan, while the MaxRisk and MaxBio plans tended to result in the largest habitat areas. When wind damage was not simulated, the MaxRisk plan underestimated the suitable habitat area the most.

\section{Effect of deadwood, harvested volume and NPV on habitat suitability}

The HSI values correlated positively with the amount of deadwood ( $r=0.797-0.917)$, regardless of the microclimatic preferences of the species group (Fig. 5). HSI also correlated positively with species-specific amounts of deadwood ( $r=0.818-0.835)$.

At the beginning of the simulation, the calculated total amount of deadwood was $2.2 \mathrm{Mg} \mathrm{ha}^{-1}$ (with diameter $>10 \mathrm{~cm}$ ). At the end of the 30-year simulation period, the total amount of deadwood ranged from 7.3 to $8.6 \mathrm{Mg} \mathrm{ha}^{-1}$ with the even-flow harvesting constraint, and from 5.5 to $8.9 \mathrm{Mg} \mathrm{ha}^{-1}$ without the even-flow harvesting constraint, depending on the management plan. Therefore, the even-flow constraint for harvested wood reduced the differences between management plans. Plans maximizing either the risk of wind damage (MaxRisk) or biodiversity (MaxBio) yielded the highest amount of deadwood (Fig. 6).

Of the total amount of deadwood, $38-72 \%$ was accounted for by wind-thrown trees and the remaining

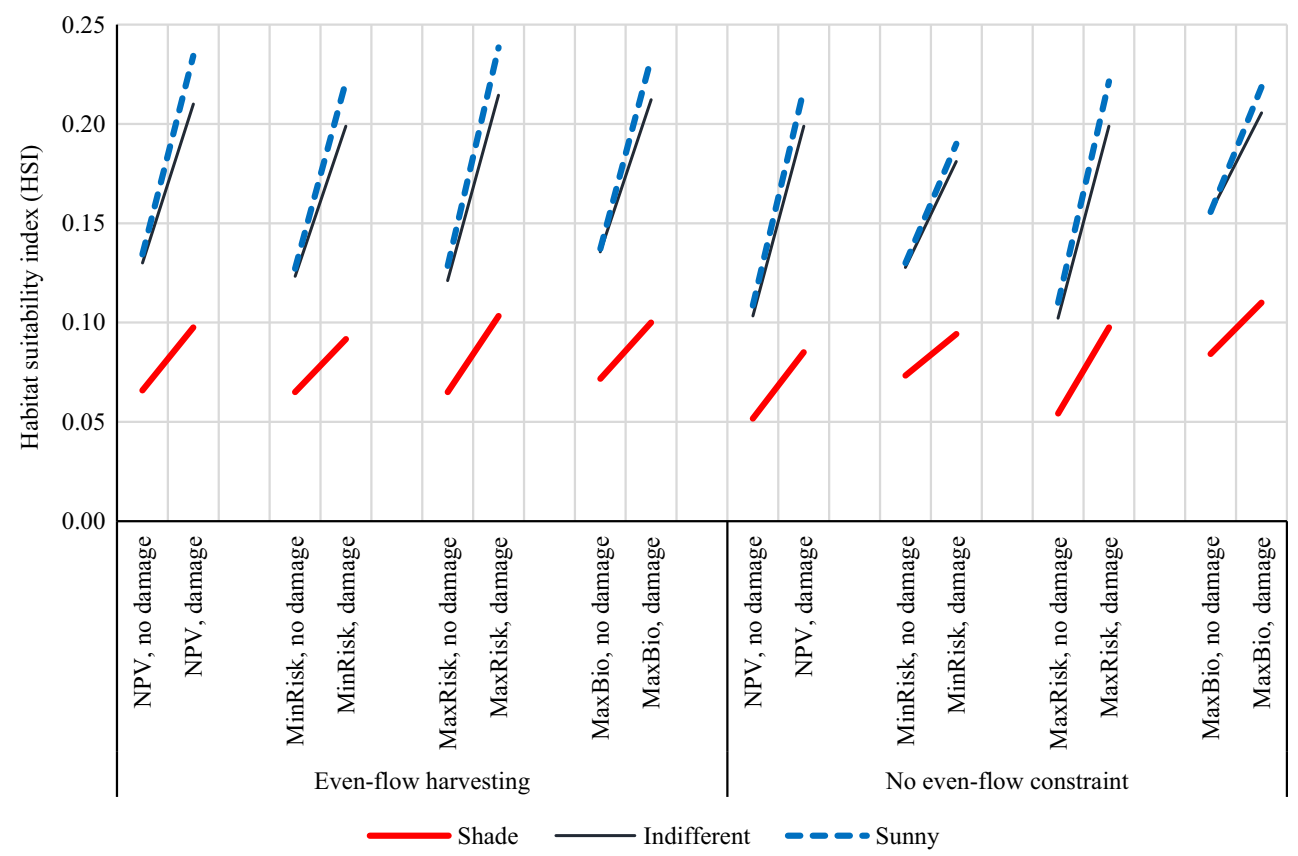

Fig. 3 Average habitat suitability index (HSI) values in 2047 by species groups (shade, sunny, and indifferent), without (no damage) and with the simulation of wind damage (damage) for four management plans developed with and without even-flow harvesting constraints (see details for management plans in Table 1) 


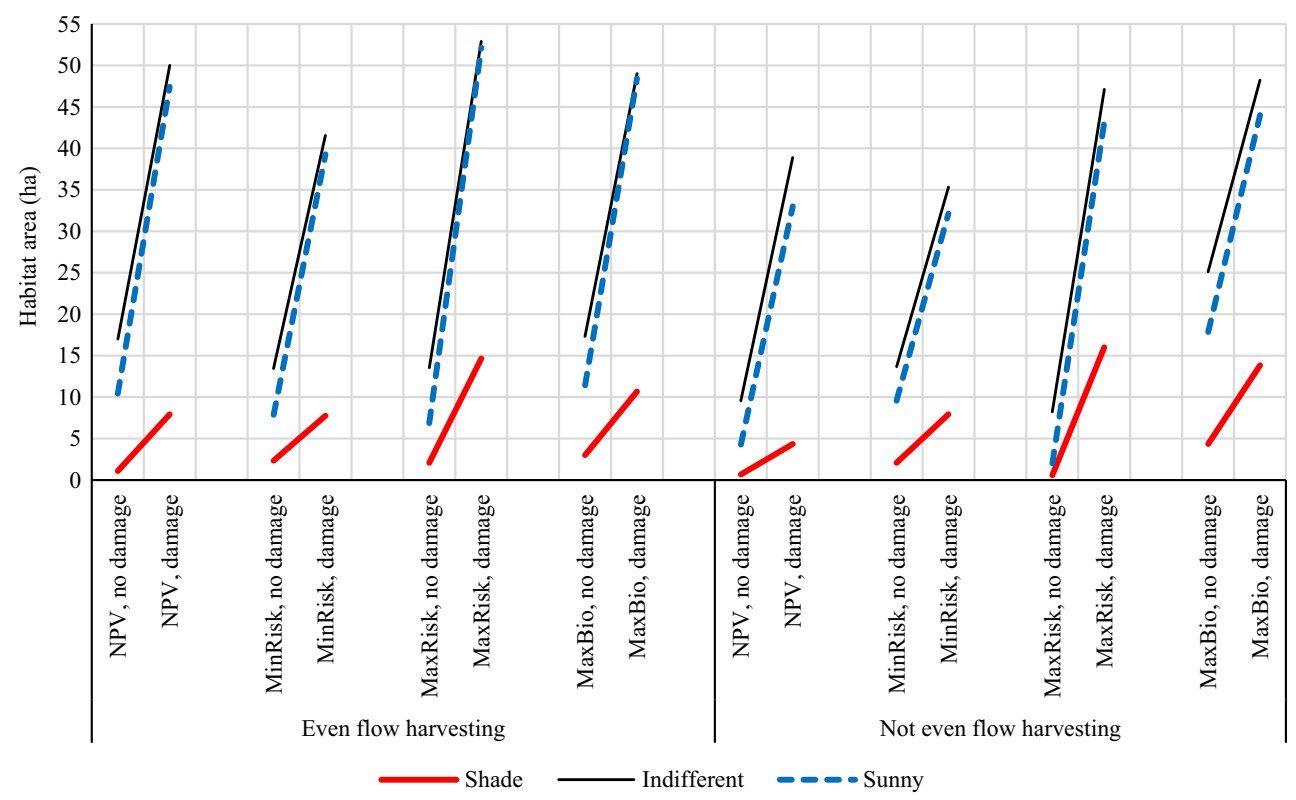

Fig. 4 Habitat area in 2047 for species groups (shade, sunny and indifferent), obtained without (no damage) and with the simulation of wind damage (damage) for four management plans developed with and without even-flow harvesting constraints (information on management plans in Table 1)

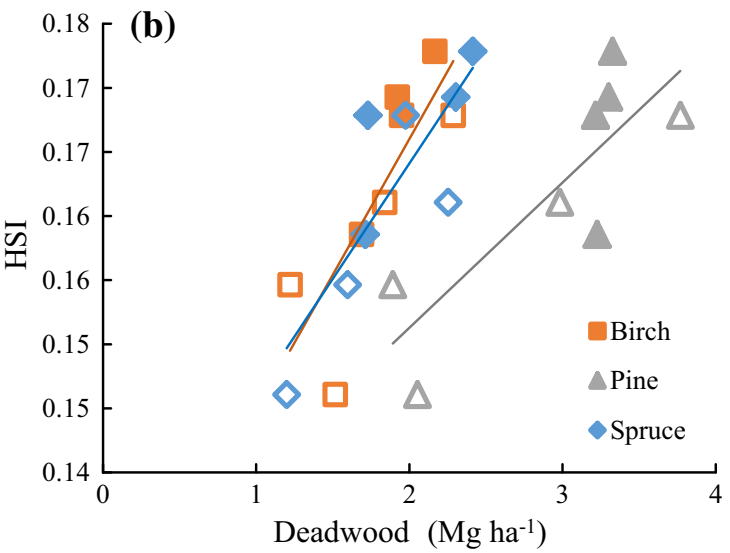

saproxylic species (b) in the last simulation year (2047). Filled markers represent plans with even-flow harvesting constraints and open markers represent plans without even-flow harvesting constraints

When the amount of harvested timber or NPV increased, the mean HSI values decreased for the shade-demanding species group (Fig. 7). In this species category, the correlation coefficient between harvested volume and HSI was -0.720 , and the correlation between NPV and HSI was -0.838 . The mean HSI values of light-demanding and indifferent species groups did not correlate strongly with the amount of harvested timber or with the NPV ( $r=0.006-0.269$ for light-demanding species, and $r=$ $-0.116-0.057$ for indifferent species). 
Fig. 6 Dry mass of deadwood $\left(\mathrm{Mg} \mathrm{ha}^{-1}\right)$ of different tree species in 2047, without (no damage) and with the simulation of wind damage (damage) in four management plans developed with and without even-flow harvesting constraints (information on management plans in Table 1)

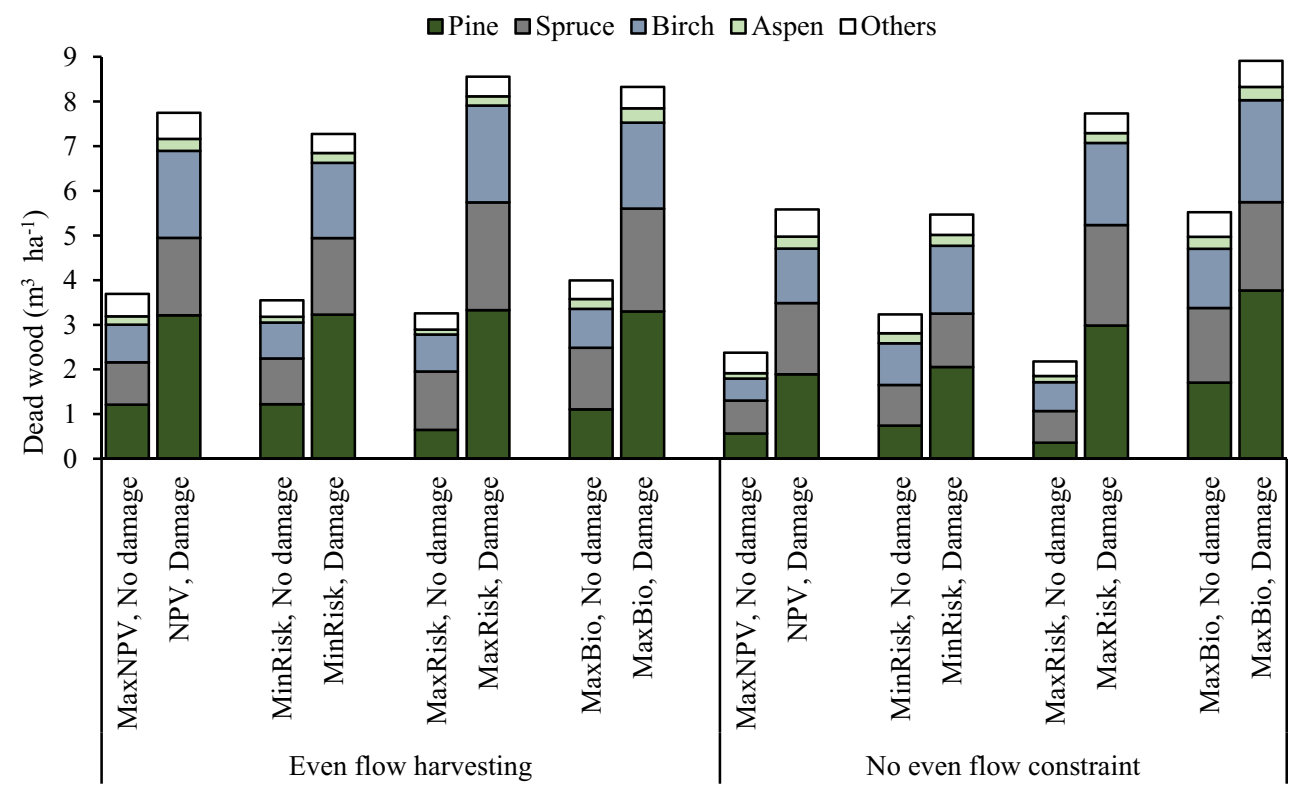

(a)

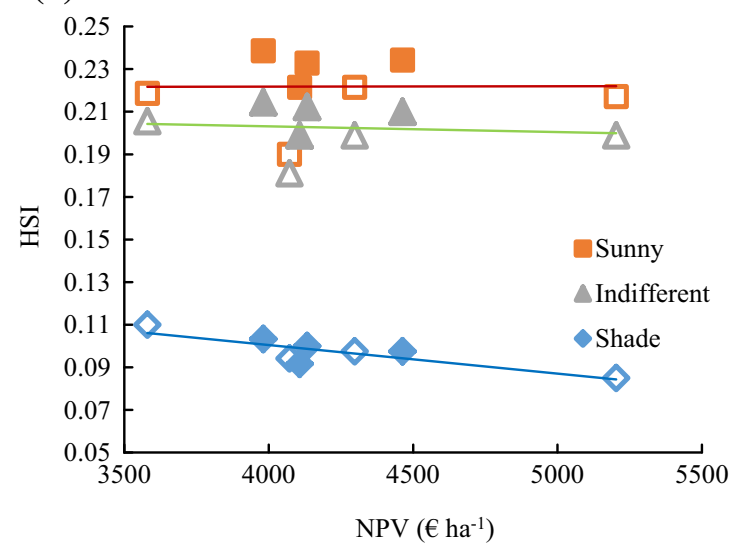

Fig. 7 Relationship between mean HSI in 2047 and NPV (a) or harvested volume of timber (b) for the eight management plans (filled markers represent plans with even-flow harvesting constraints and open markers represent plans without harvesting constraints) for

\section{Discussion}

Some years ago, the 27 groups of saproxylic species analyzed in this work accounted for roughly $70 \%$ of all redlisted forest species in a Finnish boreal forest area in eastern Finland (Tikkanen et al. 2007). Our study showed that wind-thrown trees may greatly contribute to the viability of these species in managed boreal forests. Our study also showed that omitting wind damage from calculations will result in underestimated predictions of the amount of deadwood and, consequently, underestimated values of habitat suitability indices and habitat areas. This underestimation would be larger for fragmented landscapes than for smooth continuous landscapes, as we demonstrated in (b)

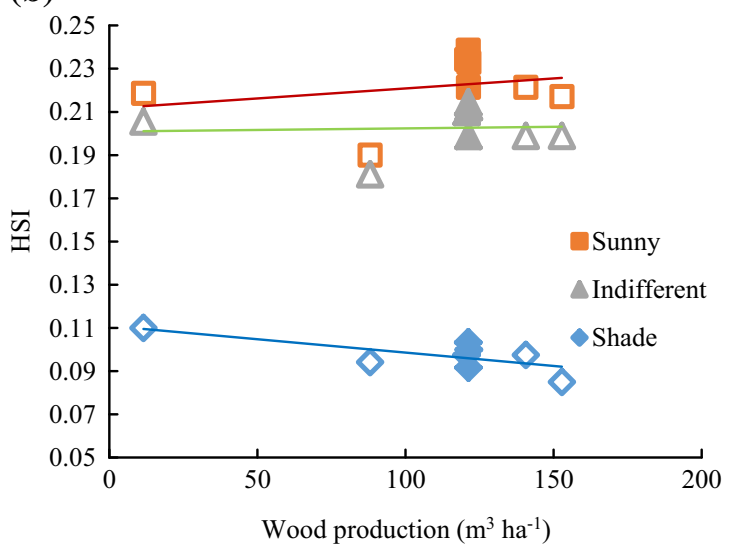

species groups with different microclimate preferences (sunny, shade, and indifferent). The lines show the linear relationship between NPV or wood production and HSI

this study. However, our study may overestimate the effect of wind damage on the habitat suitability of shade-demanding saproxylic species since most wind damage occurs near stand edges. This is because shade was described by the mean basal area of the whole stand when calculating the HSIs. Wind damage decreases basal area near stand edges and, as a consequence, especially the southern edges of mature stands may become too sunny for shade-demanding species although there may be plenty of suitable deadwood.

We assumed that only trees near stand edge are vulnerable to wind damage. This assumption was done because previous studies indicate that most wind damage in Finnish conditions occurs at stand edges adjacent to newly clear-cut areas. Only heavily thinned mature stands are 
prone to have damage in their inner parts for a few years after thinning (Laiho 1987; Peltola et al. 1999; ZubizarretaGerendiain et al. 2012).

In our boreal forest landscape, the amount of deadwood resulting from wind damage was greatest in the MaxRisk plan, which resulted in a fragmented landscape with large height differences between neighboring stands. Fragmented forest landscapes have been found to increase wind damage also in previous studies (Zeng et al. 2004; Zubizarreta-Gerendiain et al. 2017). In this study, the amount of deadwood caused by competition-induced mortality was greatest under the MaxBio plan. The MaxRisk and MaxBio plans resulted in the highest total amount of deadwood, roughly $30-40 \mathrm{~m}^{3} \mathrm{ha}^{-1}\left(7-9 \mathrm{Mg} \mathrm{ha}^{-1}\right)$, at the end of the 30 -year simulation period. Wind damage increases mainly the amount of large-sized deadwood, which is crucial for many species and usually scarce in managed forests (Lassauce et al. 2011, 2012).

In general, leaving wind-damaged trees to forest may be regarded beneficial to forest biodiversity (Kuuluvainen 2002; Lassauce et al. 2011; Thorn et al. 2014, 2017; Thom and Seidl 2016; Kulakowski et al. 2017). It may also offer a cost-efficient means to increase the amount of deadwood because the economic value of wind thrown trees is clearly lower than that of undamaged trees. Relatively high amount of deadwood (over $20 \mathrm{~m}^{3} \mathrm{ha}^{-1}$ ) is preferred by many saproxylic species. This amount of deadwood is rarely available in managed forests where good economic profitability is pursued (e.g. Lassauce et al. 2011; Gossner et al. 2013). However, our study showed that competitioninduced mortality and wind damage, when put together, may produce sufficient quantities of deadwood.

Unfortunately, the beneficial effects of wind damage are obtained at the cost of increased forest fragmentation. A high degree of fragmentation may be detrimental for biodiversity despite increasing amount of deadwood because fragmentation decreases the connectivity between suitable habitat patches and resources (Tikkanen et al. 2007). In addition, damaged trees should preferably be harvested if their number is high because damaged trees may contribute to severe outbreaks of bark beetles (Stadelmann et al. 2013; Thorn et al. 2014).

Our study did not consider the effects of climate change on biodiversity indicators. Climate change is expected to increase the growth and growing stock volume of forests, but it also increases abiotic and biotic disturbances, of which biodiversity may benefit due to increased amount of deadwood (Kellomäki et al. 2008; Mazziotta et al. 2014, 2015; Thom and Seidl 2016; Thorn et al. 2017). On the other hand, climate change may enhance the decomposition of dead wood, which may reduce the resource availability for some species (Mazziotta et al. 2014). Therefore, future studies are required to analyze the interactive effects of management and climate change on different biotic and abiotic disturbances to forests and the amount of and type of deadwood.

Open Access This article is distributed under the terms of the Creative Commons Attribution 4.0 International License (http://crea tivecommons.org/licenses/by/4.0/), which permits unrestricted use, distribution, and reproduction in any medium, provided you give appropriate credit to the original author(s) and the source, provide a link to the Creative Commons license, and indicate if changes were made.

\section{References}

Äijälä O, Koistinen A, Sved J, Vanhatalo K, Väisänen P (eds) (2014) Hyvän metsänhoidon suositukset-Metsänhoito (Recommendations for good silviculture). Publications of the Forestry Development Centre Tapio. 264 p. ISBN 978-952-6612-22-5 (in Finnish)

Beudert B, Bässler C, Thorn S, Noss R, Schröder B, Dieffenbach-fries H, Foullois N, Müller J (2015) Bark beetles increase biodiversity while maintaining drinking water quality. Conserv Lett 8(4):272-281

Finnish Statistical Yearbook of Forestry (2014) Finnish Forest Research Institute

Gossner MM, Lachat T, Brunet J, Isacsson G, Bouget C, Brustel H, Brandl R, Weisser WW, Mueller J (2013) Current near-to-nature forest management effects on functional trait composition of saproxylic beetles in beech forests. Conserv Biol 27:605-614

Gregow H (2013) Impacts of strong winds, heavy snow loads and soil frost conditions on the risks to forests in Northern Europe. Contrib Finn Meteorol Inst 94:1-178

Heinonen T, Pukkala T, Ikonen V-P, Peltola H, Venäläinen A, Dupont $S$ (2009) Integrating the risk of wind damage into forest planning. For Ecol Manag 258:1567-1577. https://doi.org/10. 1016/j.foreco.2009.07.006

Junninen K, Similä M, Kouki J, Kotiranta H (2006) Assemblages of wood inhabiting fungi along the gradients of succession and naturalness in boreal pine dominated forests in Fennoscandia. Ecography 29:75-83

Kellomäki S, Peltola H, Nuutinen T, Korhonen KT, Strandman H (2008) Sensitivity of managed boreal forests in Finland to climate change, with implications for adaptive management. Philos Trans R Soc B Biol Sci 363(1501):2341-2351

Kouki J, Tikkanen OP (eds) (2007) Uhanalaisten lahopuulajien elinympäristöjen turvaaminen suojelualueilla ja talousmetsissä (Conservation of Threatened Saproxylic Species Assemblages in Eastern Finland) Suomen Ympäristö-The Finnish Environment, 24/2007:1-104 (in Finnish with English summary)

Kulakowski D, Seidl R, Holeksa J, Kuuluvainen T, Nagel T, Panayotov M, Svoboda M, Thorn S, Vacchiano G, Whitlock C, Wohlgemuth T, Bebi P (2017) A walk on the wild side: disturbance dynamics and the conservation and management of European mountain forest ecosystems. For Ecol Manag 388:120-131. https://doi.org/10.1016/j.foreco.2016.07.037

Kuuluvainen T (2002) Introduction disturbance dynamics in boreal forests: defining the ecological basis of restoration and management of biodiversity. Silva Fenn 36(1):5-11

Laasasenaho J (1982) Taper curve and volume equations for pine spruce and birch. Commun Inst For Fenn 108:1-74

Laiho O (1987) Metsiköiden alttius tuulituhoille Etelä-Suomessa [Susceptibility of forest stands to wind throw in Southern 
Finland]. Folia For 706:1-24 (in Finnish with English summary)

Lassauce A, Paillet Y, Jactel H, Bouget C (2011) Deadwood as a surrogate for forest biodiversity: meta-analysis of correlations between deadwood volume and species richness of saproxylic organisms. Ecol Ind 11:1027-1039

Lassauce A, Lieutier F, Bouget C (2012) Woodfuel harvesting and biodiversity conservation in temperate forests: effects of logging residue characteristics on saproxylic beetle assemblages. Biol Conserv 147:204-212

Lockwood C, Moore T (1992) Harvest scheduling with spatial constraints: a simulated annealing approach. Can J For Res 23:468-478

Martikainen P, Siitonen J, Punttila P, Kaila L, Rauh J (2000) Species richness of Coleptera in mature managed and old-growth boreal forests in southern Finland. Biol Concerv 94:199-209

Mazziotta A, Mönkkönen M, Strandman H, Routa J, Tikkanen O-P, Kellomäki S (2014) Modeling the effects of climate change and management on the dead wood dynamics in boreal forest plantations. Eur J For Res 133:405-421. https://doi.org/10.1007/ s10342-013-0773-3

Mazziotta A, Triviño M, Tikkanen O-P, Kouki J, Strandman H, Mönkkönen M (2015) Applying a framework for landscape planning under climate change for the conservation of biodiversity in the Finnish boreal forest. Glob Change Biol 21:637-651

Meilby H, Niels Strange N, Thorsen BJ (2001) Optimal spatial harvest planning under risk of windthrow. For Ecol Manag 149(1-3):15-31

Mönkkönen M (1999) Managing Nordic boreal forest landscapes for biodiversity: ecological and economic perspectives. Biodivers Conserv 8:85-99

Müller J, Bütler R (2010) A review of habitat thresholds for dead wood: a baseline for management recommendations in European forests. Eur J For Res 129:981-992

Peltola H, Kellomäki S, Väisänen H, Ikonen V-P (1999) A mechanistic model for assessing the risk of wind and snow damage to single trees and stands of Scots pine, Norway spruce and birch. Can J For Res 29:647-661

Penttilä R, Siitonen J, Kuusinen M (2004) Polypore diversity in managed and old-growth boreal Picea abies forests in southern Finland. Biol Conserv 117:271-283

Pukkala T (2004) Dealing with ecological objectives in the Monsu planning system. Silva Lusitana Special issue:1-15

Pukkala T (2005) Metsikön tuottoarvon ennustemallit kivennäismaan männiköille, kuusikoille ja rauduskoivikoille. Metsätieteen aikakauskirja 3(2005):311-322

Pukkala T (2006) Optimising the semi-continuous cover forestry of Finland. Allgemaine Forst und Jagdzeitung 1677:141-149

Pukkala $T$ (2008) Integrating multiple services in the numerical analysis of landscape design. In: von Gadow K, Pukkala T (eds) Designing green landscapes. Managing forest ecosystems, vol 15, pp 137-167

Pukkala T, Lähde E, Laiho O (2013) Species interactions in the dynamics of even- and uneven-aged boreal forests. J Sustain For 32:1-33. https://doi.org/10.1080/10549811.2013.770766

Rummukainen A, Alanne H, Mikkonen E (1995) Wood procurement in the pressure of change-resource evaluation model till year 2010. Acta For Fenn 248:1-9
Seidl R, Rammer W, Blennow K (2014) Simulating wind disturbance impacts on forest landscapes: tree-level heterogeneity matters. Environ Model Softw 51:1-11

Siitonen J (2001) Forest management, coarse woody debris and saproxylic organisms: Fennoscandian boreal forests as an example. Ecol Bull 49:11-42

Similä M, Kouki J, Martikainen P (2003) Saproxylic beetles in managed and seminatural Scots pine forests: quality of dead wood matters. For Ecol Manag 174:365-381

Stadelmann G, Bugmann H, Meier F, Wermelinger B, Bigler C (2013) Effects of salvage logging and sanitation felling on bark beetle (Ips typographus L.) infestations. For Ecol Manag 305:273-281. https://doi.org/10.1016/j.foreco.2013.06.003

Tarasov ME, Birdsey RA (2001) Decay rate and potential storage of coarse woody debris in the Leningrad region. Ecol Bull 49:137-147

Tarp P, Helles F (1997) Spatial optimisation by simulated annealing and linear programming. Scand J For Res 12:390-402. https:// doi.org/10.1080/02827589709355428

Thom D, Seidl R (2016) Natural disturbance impacts on ecosystem services and biodiversity in temperate and boreal forests. Biol Rev 91:760-781. https://doi.org/10.1111/brv.12193

Thorn S, Bässler C, Gottschalk T, Hothorn T, Bussler H, Raffa K, Müller J (2014) New insights into the consequences of postwindthrow salvage logging revealed by functional structure of saproxylic beetles assemblages. PLoS ONE 9(7):1-8. https://doi. org/10.1371/journal.pone.0101757

Thorn S, Bässler C, Svoboda M, Müller J (2017) Effects of natural disturbances and salvage logging on biodiversity-lessons from the Bohemian forest. For Ecol Manag 388:113-119. https://doi. org/10.1016/j.foreco.2016.06.006

Tikkanen O-P, Martikainen P, Hyvärinen E, Junninen K, Kouki J (2006) Red-listed boreal forest species of Finland: associations with forest structure, tree species and decaying wood. Ann Zool Fenn 43:373-383

Tikkanen O-P, Heinonen T, Kouki J, Matero J (2007) Habitat suitability models of saproxylic red-listed boreal forest species in long-term matrix management: cost-effective measures for multi-species conservation. Biol Conserv 140:359-372

Zeng $\mathrm{H}$, Peltola $\mathrm{H}$, Talkkari A, Venäläinen A, Strandman H, Kellomäki S, Wang K (2004) Influence of clear-cutting on the risk of wind damage at forest edges. For Ecol Manag 203:77-88

Zeng H, Pukkala T, Peltola H (2007) The use of heuristic optimisation in risk management of wind damage in forest planning. For Ecol Manag 241:189-199

Zubizarreta-Gerendiain A, Pellikka P, Garcia-Gonzalo J, Ikonen V-P, Peltola H (2012) Factors affecting wind and snow damage of individual trees in a small management unit in Finland: assessment based on inventoried damage and mechanistic modelling. Silva Fenn 46(2):181-196

Zubizarreta-Gerendiain A, Pukkala T, Peltola H (2017) Effects of wind damage on the optimal management of boreal forests under the current and changing climatic conditions. Can J For Res 47(2):246-256. https://doi.org/10.1139/cjfr-2016-0226 